\title{
The Solutrean-Magdalenian transition: A view from Iberia
}

\author{
J. Emili Aura ${ }^{\mathrm{a}, *}$, Marc Tiffagom ${ }^{\mathrm{b}}$, Jesús F. Jordá Pardo ${ }^{c}$, Elsa Duarte ${ }^{\mathrm{d}}$, Javier Fernández de la Vega ${ }^{\mathrm{d}}$, \\ David Santamaria $^{\mathrm{d}}$, Marco de la Rasilla ${ }^{\mathrm{d}}$, Margarita Vadillo ${ }^{\mathrm{e}}$, Manuel Perez Ripoll ${ }^{\mathrm{e}}$ \\ ${ }^{a}$ University of Valencia, Prehistória i Arqueologia, Avda. Blasco Ibañez, 28, Valencia 46010, Spain \\ ${ }^{\mathrm{b}}$ Museu de Prehistoria, Valencia, Spain \\ ${ }^{\mathrm{c}}$ Laboratorio de Estudios Paleolíticos, UNED Madrid, Spain \\ ${ }^{\mathrm{d}}$ Area de Prehistoria, Universidad de Oviedo, Oviedo, Spain \\ ${ }^{\mathrm{e}}$ Dept. Prehistoria i Arqueologia, Universitat de Valencia, Valencia, Spain
}

\section{A R T I C L E I N F O}

Article history:

Available online 18 May 2012

\begin{abstract}
A B S T R A C T
The paper examines the Upper Solutrean-Archaic Magdalenian/Badegoulian succession on the base of lithic and bone tool production, chrono-stratigraphic data and radiocarbon dates from the Cantabrian and Mediterranean regions of Iberia, mainly the areas of Asturias and Valencia (Spain). The discussion considers a reduced number of variables (characteristic stone tools, bone points and decoration techniques) and highlights the elements in common. The analysis concerning the transformation of lithic production at Cova del Parpalló provides new data for the Upper Solutrean-Archaic Magdalenian/ Badegoulian transition.
\end{abstract}

(c) 2012 Elsevier Ltd and INQUA. All rights reserved.

\section{Introduction}

The techniques used for the manufacture of Solutrean stone points changed during the Last Glacial Maximum (hereafter LGM), ca. 23-19 ka cal BP). For more than two millennia, human groups in France and the Iberian Peninsula had shared these techniques, but with progressively more marked regional diversification (Jordá Cerdá, 1955; Smith, 1966; Fullola, 1979; Straus, 1983; Rasilla Vives, 1989, 1994; Villaverde and Fullola, 1990; Zilhão, 1997; Tiffagom, 2006; Banks et al., 2009). Changes in lithic production along with a shift towards an increase in the use of bone points allow differentiation of a new archaeological techno complex known as Archaic Magdalenian or Badegoulian (Cretin, 2007). As implied by the continued use of these two terms, something which is still a matter of debate, a complex relationship exists between the Upper Solutrean and the succeeding Archaic Magdalenian/Badegoulian. The term Magdalenian was widely accepted on the basis of the six phases recognized by Breuil (1912). However, almost all the diagnostic elements of the early Magdalenian horizon originate from Badegoulian type sites. There is flake and raclette production at Badegoule, antler debitage by percussion at Abri Fritsch, bone points with single basal bevel with bracket-sign incised marks (Le Placard type), and the pseudo-excise carving technique (short

\footnotetext{
* Corresponding author.

E-mail address: Emilio.aura@uv.es (J.E. Aura).
}

continuous incisions) at Badegoule and Le Placard. Nonetheless, all these elements are still characterized as Magdalenian.

The transition is not only defined by the shift from stone points to ones made of bone. In the Cantabrian region, the continuity between the archaeological cultures referred to as Solutrean and Magdalenian is widely accepted in the literature (Corchón, 1981, 1994: 134; Straus and Clark, 1986: 375; Rasilla Vives, 1994: 73; Rasilla Vives and Straus, 2006). Moreover, the convergence of certain artifacts types, raw material use and decoration techniques and patterns indicates that exchange processes between regional groups were taking place (Barandiarán, 1973; Sacchi, 1986; Utrilla, 1986; Fortea, 1989; González Morales and Straus, 2009). For the Mediterranean region, a change in lithic and bone tool industries is suggested, pointing to contacts with southeast France and the Cantabrian-Pyrenees region (Villaverde, 1994; Aura Tortosa, 1995, 2007; Villaverde et al., 1998).

Another view of the transition goes beyond the succession of characteristic tool types and suggests the existence of a dynamic relationship between with palaeoclimatic change and interaction between regional groups. It is likely that two factors played a decisive role in this transformation. New demographic dynamics during the LGM (Straus and Clark, 1986) and new relationships between groups that may be inferred from the distribution of shared patterns and conventions in Palaeolithic art in southwest Europe (Sauvet et al., 2008). Barton et al. (2011) have recently suggested that for a better understanding of the complexity of cultural transmission mechanisms, multidimensional models that 
combine biological, cultural and environmental data are required. Banks et al. (2011), in their study of the French Badegoulian, applied an eco-cultural niche model geared towards examining the relationship between ecological and cultural systems. Data concerning lithic raw material circulation and production systems allowed them to identify distinct social territories within a single ecological niche. The present study assesses the presence and association of certain descriptors of the lithic and bone/antler industries.

\section{LGM industries in Iberia: antecedents and regional data}

Iberia is located at the southwest of Europe and is characterized by concentrations of sites in coastal areas, the Cantabrian region to the north, the Atlantic front of Portugal to the west and the Mediterranean to the east and southeast (Fig. 1). Connections with the Pyrenees-Aquitaine region were identified during early work at Altamira Cave and Castillo, and the presence of mutual influence has been accepted. Relations with Africa have also been suggested repeatedly during the past 100 or so years of research. However, apart from some typological similarities between some tools (Tiffagom, 2006b), the evidence from North Africa is insufficient for an in-depth discussion of the issue. In the southernmost regions of Iberia, located closer to Africa, rock art appears during the Gravettian (Fortea Pérez, 2005).

The Upper Palaeolithic sequence of Iberia was based on a small number of sites, mainly excavated between 1910 and 1930. They include the Atlantic sites of Cueto de la Mina (Asturias), and Cueva del Castillo (Cantabria), and then Cova del Parpalló in the
Mediterranean region of Valencia. The characteristics in common in these two areas may be summarized as follows:

a) Data from cave and rockshelter sites reveal dynamic geological processes related to unstable palaeoclimates (Fumanal, 1986; Jordá Pardo, 1992; Hoyos, 1994; Bergadá, 1998) and complex taphonomic problems (trampling, etc). At some sites, these processes may have been responsible for the mixing of Upper Solutrean and Magdalenain-Badegoulian artifacts, as has been noted at some French sites (cf. Aubry et al., 2007).

b) Blade blanks, Solutrean retouch, bifacial working and the production of shouldered points are essential elements of the Solutrean technique (Rasilla Vives, 1994). Another characteristic is the thermal treatment of flint (Tiffagom, 1998), together with regional diversity in certain types of Solutrean points (Straus, 1990; Rasilla Vives and Santamaria, 2006; Tiffagom, 2006).

c) The end of the Solutrean is followed by changes in lithic production. The generally accepted characteristics, that nevertheless need to be further refined, include the use of local raw materials and the abandonment of blade blanks for points, replaced by more expedient production of short blades and flakes (tools with an "archaic" appearance). In parallel with these changes in lithic production was an increase in bone industries.

d) The longer duration of the Solutrean in Iberia compared to the French regions (Jordá Cerdá, 1955; Fortea and Jordá Cerdá, 1976; Utrilla, 1981, 1989; Straus, 1983; Villaverde and Fullola, 1990; Rasilla Vives and Llana, 1994; Corchón, 1999), resulted in a somewhat late chronology for the Archaic

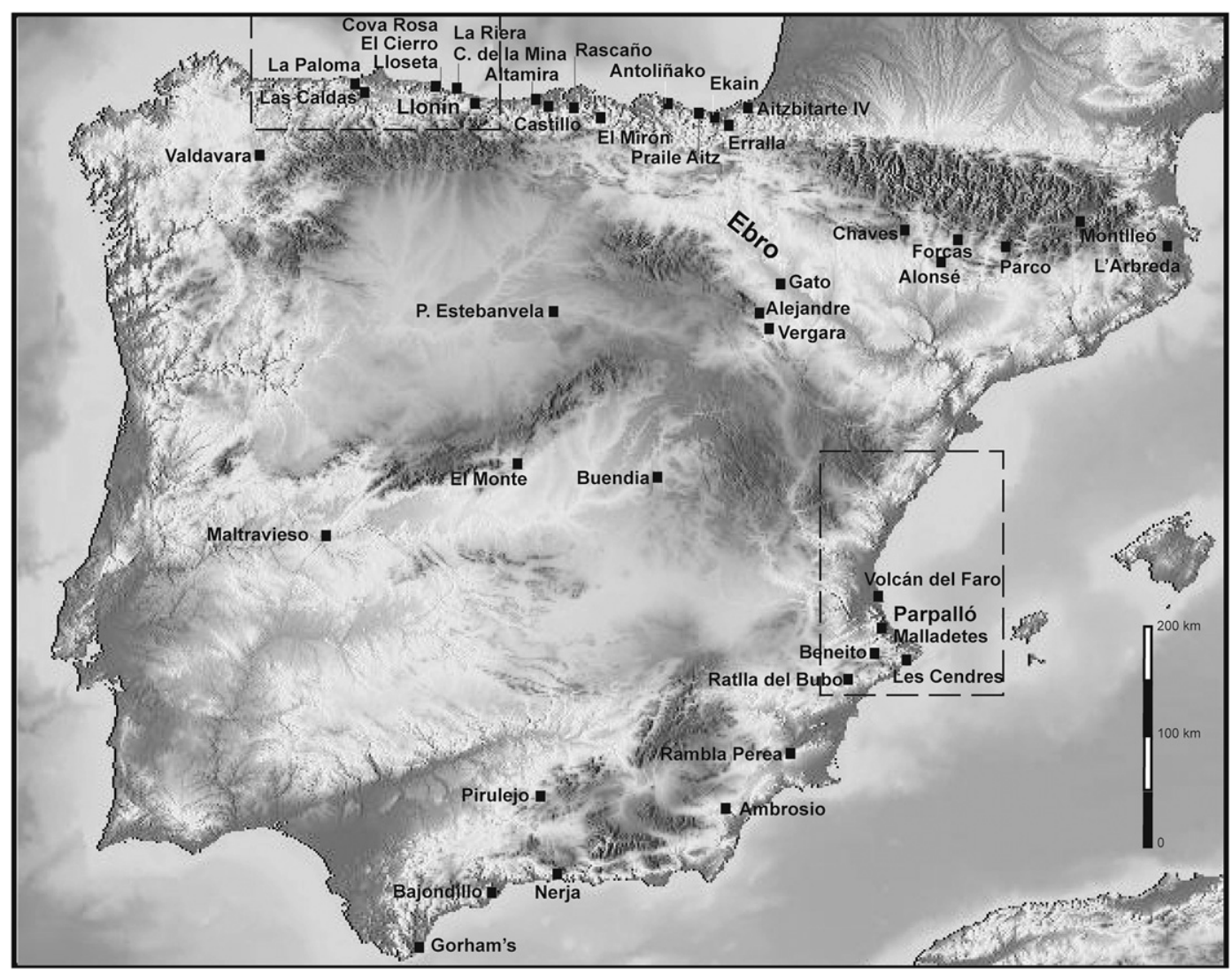

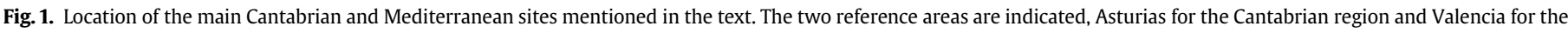
Mediterranean. 
Magdalenian/Badegoulian (Utrilla, 1981, 2006; Utrilla and González Sainz, 2003; Aura Tortosa, 1995, 2007). Further discussion and analysis of the chronological framework established by the available radiocarbon dates may provide a better understanding of the overall transition process.

\subsection{Data from the Cantabrian region}

The "transition" in the Cantabrian sites coincides with erosion (Hoyos, 1994) and taphonomic processes. The use of the terms Archaic Magdalenian (AM) and Badegoulian (BA), which may be confusing, is closely related to the historical roots of the research in different regions. In Iberia, the former (AM) is mostly preferred in the Cantabrian region, while the latter (BA) has been used for Cova del Parpalló in the Mediterranean region. This is one of the typesites used by A. Cheynier $(1939,1951)$ to define the "ProtoMagdalenian" (the initial phases of the Magdalenian) that was finally named Badegoulian by Vignard (1965).

In relation to the Archaic Magdalenian (AM), Utrilla (1981, 2006) suggests that after the Cantabrian Upper Solutrean (US) assemblages dated to between 22 and $19.5 \mathrm{ka}$ cal BP may be grouped into three partly contemporary facies (Fig. 2):

- A "transitional" group identified at Caldas 3 (chamber I) and XIVc (chamber II) and at La Riera (8-15), both in Asturias, amongst other sites. This group corresponds to what has been termed Final Solutrean or "de-solutreanized" (Straus, 1975; Corchón, 1981; Rasilla Vives, 1994). At La Riera, Straus and
Clark (1986) highlighted the use of local raw materials for the production of an "archaic" toolkit, some raclettes and the variable presence of bladelets which are more abundant in the recently excavated sites (Straus and González, 2007).

- A second group is characterized by raclettes and the pseudoexcise decoration technique described by Barandiarán (1973, pp. 258), and associated with Archaic MagdalenianBadegoulian contexts (Utrilla, 1986; Seronie Vivien, 2005). This facies is identified at Aitzbitarte IV (Basque Country).

These two groups would fall within the so-called Cantabrian Badegoulian as has been described by Bosselin and Djindjian (1999).

- A third group termed archaic Magdalenian of Rascaño - 5 type includes a few raclettes and flat section sagaie antler points with large single basal bevel, with a concave profile that ends in a small tongue and bears a Le Placard type bracket-sign decoration (Utrilla, 1981). The dates for Castillo -8 and Rascaño -5 , both in Cantabria, are bracketed between 21 and 20 ka cal BP.

After $19.5 \mathrm{ka}$ cal BP, the Cantabrian Lower Magdalenian (LM) sites with blade/bladelets and square section sagaie multiply. This horizon is characterized by greater technological stability (Utrilla, 2006; Cazals and Bracco, 2007).

The relationship among the three AM facies is still debated. The analysis of their lithic industries will possibly allow connections with other regions to be identified (Corchón, 2005; Straus et al.,

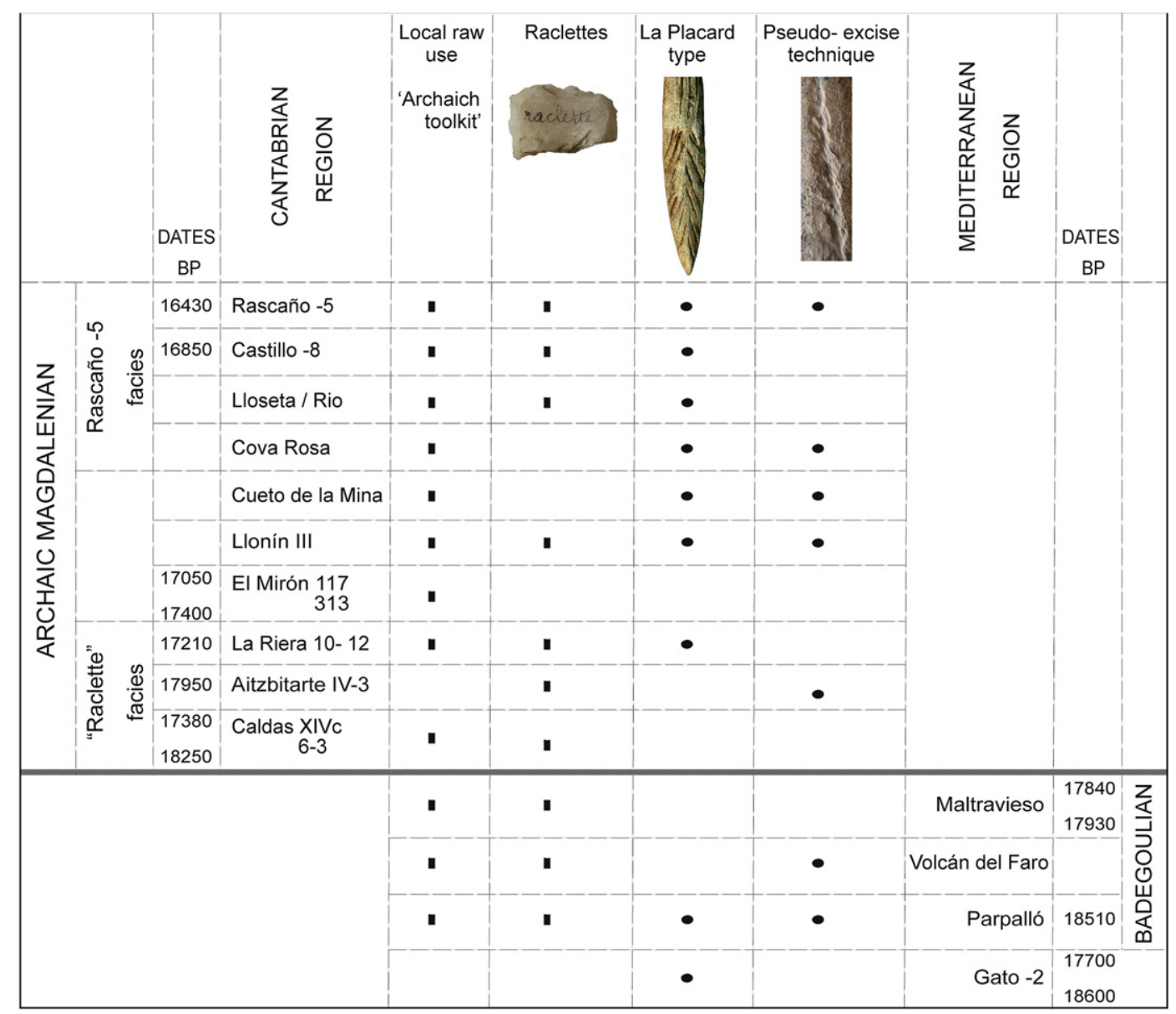

Fig. 2. Presence of the lithic and bone industry descriptors mentioned in the text in the main AM and BA sites of the Cantabrian and the Mediterranean regions respectively. 
2008). Common elements may be encountered in all three groups, but it is only at Llonín III (Galeria) where all of the three facies are found in association. This particular context at Llonin (Asturias) is strongly affected by fire related activities and points to the predominant use of local quartzite and radiolarite raw materials (Fortea et al., 1995, 2004, 2007).

Discoidal-facial-Levallois type percussion was employed at Llonín to obtain large quartzite flake blanks for the manufacture of most retouched tools including notches, denticulates, side-scrapers and splintered pieces. Radiolarite was abundant and was mainly used for the production of blade and bladelet blanks for endscrapers and retouched blades. In contrast to local raw materials, better quality exotic flint reached the site as blanks or finished tools. Burins, composite tools, scrapers on small flakes and raclettes were produced with these flint types. Bone tools are abundant and among them two pieces with pseudo-excise decoration and another two bone points with Le Placard type bracket-sign decoration are exceptional (Fig. 3: 2 and 11).

It has recently been suggested that these facies parallel the French Badegoulian both in chronology (22.5-20 ka cal BP) and lithic and bone/antler production (Sauvet et al., 2008).

\subsection{Data from the Mediterranean region}

Sites with long stratigraphic sequences in this region (Bajondillo, Pirulejo, Nerja, and Ambrosio are in Andalusia, while Beneito, Cendres and Malladetes are in Valencia) are frequently characterized by an erosional discontinuity during the interval 22-20 ka cal BP (Aura Tortosa, 1995, 2007). The sequence from Cova del Parpalló (Valencia) is the basic reference for the Solutrean - Magdalenian/ Badegoulian transition in the Mediterranean (Pericot, 1942; Fullola, 1979; Fortea et al., 1983; Villaverde et al., 1998; Aura Tortosa, 2007). Although there are other nearby sites with horizons similar to those defined at Parpalló as Badegoulian (BA), they originate from poorly defined contexts. The evidence from Volcán del Faro (Valencia) (Aparicio, 2003) points to a similar sequence to that from Parpallo from the end of the Solutrean to the classic Magdalenian with harpoons (Aura Tortosa, 1995). However, problems of taphonomy have frustrated attempts to radiocarbon date the sequence.

The Cantabrian facies for the US - AM succession have not been recognized in the Mediterranean region. Here the sequence consists of three cultural units:

- An Upper Solutrean (the so-called "Solutreo-Gravettian"), characterized by rare foliates and numerous Mediterranean shouldered points. At Parpalló the first short single basal bevel sagaie and a Le Placard type single bevel point appear (Pericot, 1942; pp. 70).

- A "Parpalló type" Badegoulian horizon is characterized by flake and short blade blanks and also includes a "low-investment toolkit" (notches, denticulates or side-scrapers made on flakes) and raclettes in its upper phases. Bone/antler industries include sagaie with large single basal bevel and bi-points of
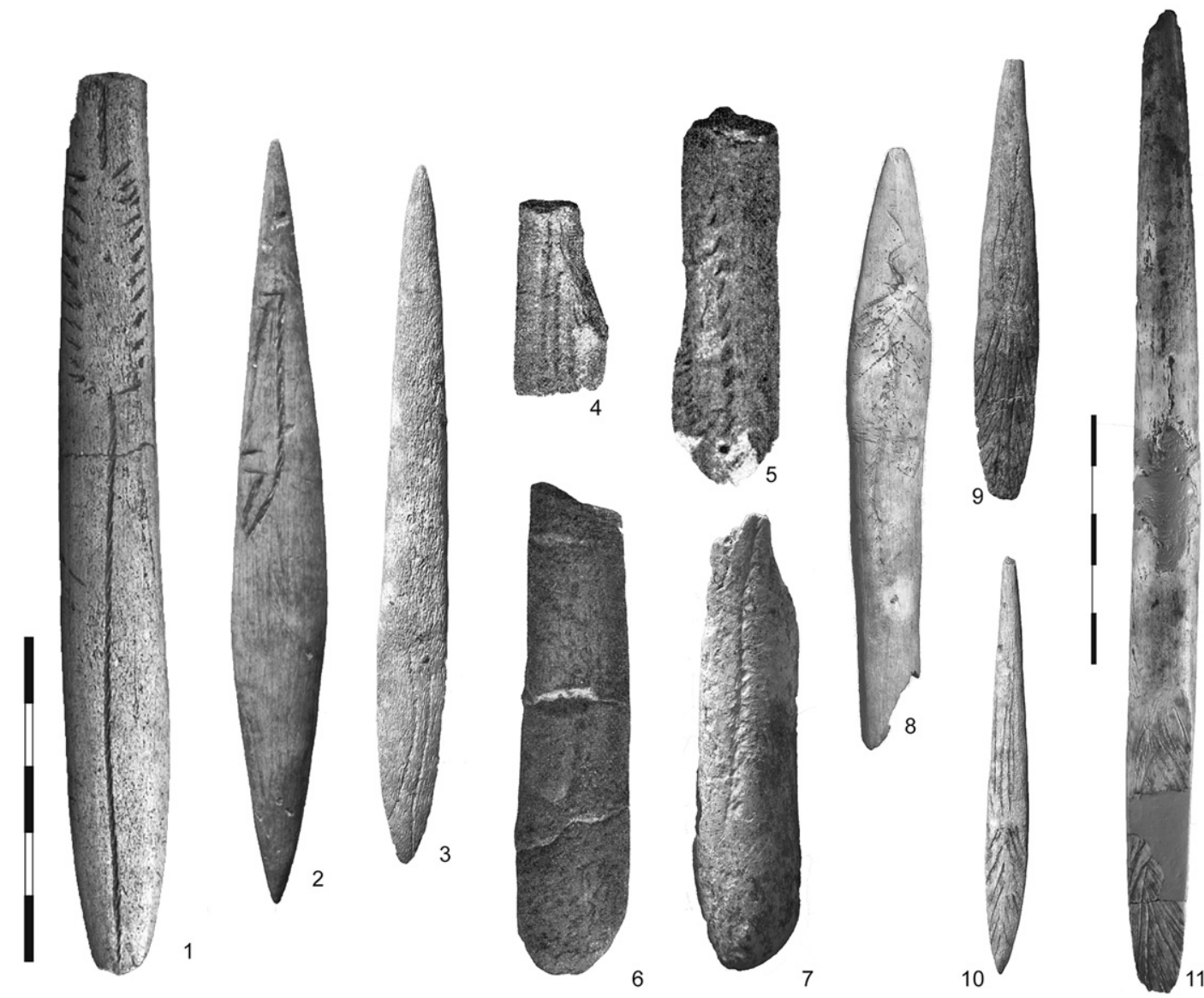

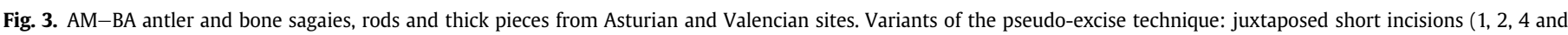

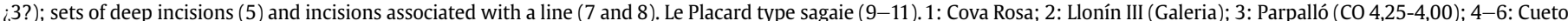

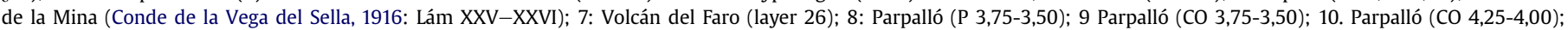
11: Llonín III (Vestíbulo). 
Table 1

List of selected radiocarbon dates from the Spanish Solutrean-Magdalenian Transition (GI 2 and GS 2).

\begin{tabular}{|c|c|c|c|c|c|c|c|c|c|}
\hline Site and level & Lab $\mathrm{Nr}$ & Date & SD & Method & Material & $\begin{array}{l}\text { CalAge BP (95\%) } \\
\{0=\text { AD } 1950\}\end{array}$ & Phase & $\begin{array}{l}\text { Phase } \\
\text { this paper }\end{array}$ & Reference \\
\hline \multicolumn{10}{|l|}{ Cantabrian Region } \\
\hline Altamira sup & GifA-90047 & 14520 & 260 & AMS & Bone & $18,140-17,060$ & LM & LM & González Echegaray, 1996 \\
\hline La Paloma -6 & OxA-974 & 14600 & 160 & AMS & Antler & $18,740-17,195$ & LM & LM & Barandiarán, 1988 \\
\hline Entrefoces & Ly-2937 & 14690 & 200 & $14 \mathrm{C}$ & & $18,520-17,990$ & LM & LM & Gionzález Morales, 1990 \\
\hline Pendo II & OxA-977 & 14830 & 130 & AMS & Antler & $18,510-18,040$ & LM & LM & Barandiarán, 1988 \\
\hline El Mirón 108 & GX-27114 & 14850 & 60 & AMS & Charcoal & $18,020-17,820$ & MM/LM & LM & Straus and Gonzalez Morales 2007 \\
\hline El Mirón 15 & GX-23392 & 15010 & 260 & $14 \mathrm{C}$ & Bone/collagen & $18,780-17,660$ & LM & LM & Straus and Gonzalez Morales 2007 \\
\hline Las Caldas II -XIII & Ua-4301 & 15165 & 160 & AMS & Bone & $18,760-17,800$ & LM & LM & Corchón, 1994 \\
\hline Rascaño 3 & BM-1452 & 15173 & 160 & $14 \mathrm{C}$ & & $18,770-17,810$ & LM & LM & $\begin{array}{l}\text { Glez. Echegaray and } \\
\text { Barandiarán, } 1981\end{array}$ \\
\hline El Mirón 16 & GX- 23415 & 15180 & 100 & AMS & Bone/collagen & $18,750-17,830$ & LM & LM & Straus and Gonzalez Morales 2007 \\
\hline La Riera 19 & Q-2116 & 15230 & 300 & $14 \mathrm{C}$ & Charcoal & $18,930-17,730$ & LM & LM & Straus and Clark, 1986 \\
\hline Ekain VIId (18-19) & $\mathrm{I}-12266$ & 15400 & 240 & $14 \mathrm{C}$ & Bone & $19,030-17,790$ & LM & LM & Altuna and Merino 1984 \\
\hline El Mirón 17 & GX-25853 & 15700 & 190 & $14 \mathrm{C}$ & Charcoal & $19,210-18,530$ & LM & LM & Straus and Gonzalez Morales 2007 \\
\hline Erralla V & I- 12868 & 15740 & 240 & $14 \mathrm{C}$ & Bone & $19,420-18,460$ & LM & LM & Altuna et al., 1985 \\
\hline Abauntz E & Ly 1965 & 15800 & 350 & $14 \mathrm{C}$ & Bone & $19,835-19,050$ & LM & LM & Utrilla, 1989 \\
\hline Praile Aitz & GrA-24685 & 15530 & 100 & AMS & Bone & $19,130-18,690$ & LM & LM & Peñalver and Mujika, 2003 \\
\hline Altamira & $\mathrm{I}-12012$ & 15910 & 230 & $14 \mathrm{C}$ & & $19,620-18,580$ & LM & LM & González Sainz, 1989 \\
\hline Ekain, VIIc 16/17 & $\mathrm{I}-12225$ & 15970 & 240 & $14 \mathrm{C}$ & Bone & $19,750-18,590$ & LM & LM & Altuna and Merino 1984 \\
\hline Rascaño 4 & BM-1453 & 15988 & 195 & $14 \mathrm{C}$ & & $19,650-18,650$ & LM & LM & $\begin{array}{l}\text { Glez. Echegaray and } \\
\text { Barandiarán, } 1981\end{array}$ \\
\hline Ekain VIIb 14/15 & $\mathrm{I}-12224$ & 16030 & 240 & $14 \mathrm{C}$ & Bone & $19,850-18,610$ & LM & LM & Altuna and Merino 1984 \\
\hline Erralla Va & $\mathrm{I}-12540$ & 16030 & 240 & $14 \mathrm{C}$ & & $19,850-18,610$ & LM & LM & Altuna et al., 1985 \\
\hline El Mirón 110 & GX-23396 & 16130 & 250 & $14 \mathrm{C}$ & Bone/collagen & $20,020-18,660$ & LM & LM & Straus and Gonzalez Morales 2007 \\
\hline Erralla Va & $\mathrm{I}-12551$ & 16270 & 240 & $14 \mathrm{C}$ & B & $20,200-18,800$ & LM & LM & Altuna et al., 1985 \\
\hline El Mirón 111 & GX-23395 & 16370 & 190 & $14 \mathrm{C}$ & Bone/collagen & $20,190-19,070$ & LM & LM & Straus and Gonzalez Morales 2007 \\
\hline Rascaño 5 & BM-1455 & 16433 & 130 & $14 \mathrm{C}$ & & $20140-19300$ & AM & AM & $\begin{array}{l}\text { Glez. Echegaray and } \\
\text { Barandiarán, } 1981\end{array}$ \\
\hline El Mirón 114 & GX-28209 & 16460 & 50 & AMS & Bone/collagen & $19,980-19,580$ & AM & AM & Straus and Gonzalez Morales 2007 \\
\hline Ekain VIIb & $\mathrm{I}-12020$ & 16510 & 270 & $14 \mathrm{C}$ & Bone & $20,530-19,050$ & LM & LM & Altuna and Merino 1984 \\
\hline Castillo -8 & OxA-971 & 16850 & 220 & AMS & Antler & $20,770-19,690$ & AM & AM & Barandiarán, 1988 \\
\hline La Riera 17 & GAK-6445 & 16900 & 200 & $14 \mathrm{C}$ & Charcoal & $20,780-19,820$ & US & AM & Straus and Clark, 1986 \\
\hline El Mirón 117 & GX-25857 & 17050 & 60 & AMS & Charcoal & $20,640-20,320$ & MA & AM & Straus and Gonzalez Morales 2007 \\
\hline Las Caldas Pasillo 4 & Ly-2422 & 17050 & 290 & $14 \mathrm{C}$ & Bone & $21,170-19,810$ & US & AM & Corchón, 1999 \\
\hline Urtiaga $\mathrm{F}$-inf & GrN-5817 & 17050 & 140 & $14 \mathrm{C}$ & Bone & $20,820-20,180$ & MA & AM & Altuna, 1972 \\
\hline La Riera 12 & Gak-6446 & 17210 & 350 & $14 \mathrm{C}$ & Bone & $21,480-19,880$ & US & AM & Straus and Clark, 1986 \\
\hline Las Caldas II -XIVc & Ua-4302 & 17380 & 215 & AMS & Bone & $21,390-20,350$ & US & AM & Corchón, 1994 \\
\hline El Mirón 313 & GX-31194 & 17400 & 270 & $14 \mathrm{C}$ & Bone/collagen & $21,510-20,270$ & LM/US & AM & Straus et al., 2008 \\
\hline Aitzbitarte IV-III & GrN-5993 & 17950 & 150 & $14 \mathrm{C}$ & Bone & $21,880-21,160$ & US / AM & AM & Altuna, 1972 \\
\hline Las Caldas Pasillo 3 & Ly-2421 & 18250 & 300 & AMS & Bone & $22,730-21,270$ & US & AM & Jordá et al., 1992 \\
\hline Las Caldas I- 11 & Ua-15316 & 18305 & 295 & AMS & Bone & $22,760-21,240$ & US & US & Corchón, 1999 \\
\hline Las Caldas Pasillo 7 & Ly-2423 & 18310 & 260 & $14 \mathrm{C}$ & Bone & $22,720-21,280$ & US & US & Jordá et al., 1992 \\
\hline $\begin{array}{l}\text { Cueto de la } \\
\text { Mina V (1981-86) }\end{array}$ & Ua-3586 & 19110 & 205 & AMS & Bone & $23,440-22,520$ & US & US & Rasilla and Llana, 1994 \\
\hline Antoliñako Koba Lmc & GrN-23785 & 19280 & 120 & $14 \mathrm{C}$ & Bone & $23,450-22,850$ & US & US & Aguirre, 1999 \\
\hline Llonín-IV & OxA-22700 & 19300 & 110 & AMS & Bone & $23,460-22,900$ & US & US & This paper \\
\hline Llonín-IV & OxA-22699 & 19330 & 100 & AMS & Bone & $23,460-22,980$ & US & US & This paper \\
\hline Las Caldas Pasillo-9 & Ly-2424 & 19390 & 260 & $14 \mathrm{C}$ & Bone & $23,790-22,670$ & US & US & Jordá et al., 1992 \\
\hline Llonín-IV & OxA-22698 & 19480 & 110 & AMS & Bone & $23,550-23,190$ & US & US & This paper \\
\hline \multicolumn{10}{|l|}{ Mediterranean Region } \\
\hline Estebanvela VI & Beta-228871 & 14450 & 80 & AMS & & $17,840-17,520$ & LM & LM & Cacho et al., 2010 \\
\hline El Monte & Beta-245814 & 14660 & 80 & AMS & Charcoal & $17,900-17,740$ & LM & LM & Cacho et al., 2010 \\
\hline Buendía 1C & Beta-212777 & 14840 & 50 & AMS & Charcoal & $17,960-17,840$ & LM & LM & Cacho et al., 2010 \\
\hline Alonsé & GrA-21537 & 14840 & 90 & AMS & Charcoal & $18,620-17,620$ & LM & LM & Utrilla and Montes, 2007 \\
\hline Cendres XIIA & BETA-118023 & 14850 & 100 & AMS & Charcoal & $18,650-17,610$ & LM & LM & Villaverde et al., 1999 \\
\hline Alonsé m & GrA-21536 & 15069 & 90 & AMS & Charcoal & $18,700-17,780$ & LM & LM & Montes, 2005 \\
\hline Alexandre IIIb & GrN-23448 & 15370 & 110 & $14 \mathrm{C}$ & Charcoal & $18,930-17,850$ & LM & LM & Utrilla and Montes, 2007 \\
\hline Montlleó sect B & OxA-9017 & 15440 & 80 & AMS & Charcoal & $18,750-18,550$ & LM & LM & Mangado et al., 2009 \\
\hline Cendres XII & Ly-5586 & 15820 & 150 & $14 \mathrm{C}$ & Charcoal & $19,270-18,630$ & LM & LM & Villaverde et al., 1999 \\
\hline Montlleó sect B & OaX-X-2234-52 & 16900 & 110 & AMS & Bone & $20,560-20,080$ & LM & LM & Mangado et al., 2009 \\
\hline Cendres XIIbase & Beta 118024 & 17230 & 130 & AMS & Charcoal & $21,010-20,370$ & US & US & Villaverde et al., 1999 \\
\hline L'Arbreda sup-A & Gif-6418 & 17320 & 290 & $14 \mathrm{C}$ & Charcoal & $21,470-20,150$ & US & US & Delibrias et al., 1987 \\
\hline Ratlla del Bubo II & Ly-5219 & 17360 & 180 & $14 \mathrm{C}$ & Charcoal & $21,310-20,390$ & US & US & Soler et al., 1990 \\
\hline Gato 2 & GrA-42226 & 17700 & 70 & AMS & B & $21,440-21,040$ & AM & $\mathrm{AM} / \mathrm{BA}$ & Blasco and Rodanés, in press \\
\hline L'Arbreda sup-B & Gif-6420 & 17720 & 290 & $14 \mathrm{C}$ & Charcoal & $21,920-20,560$ & US & US & Delibrias et al., 1987 \\
\hline Maltravieso A & Poz-30469 & 17840 & 90 & AMS & Charcoal & $21,550-21,190$ & $\mathrm{BA}$ & $\mathrm{BA}$ & Canals et al., 2010 \\
\hline Parpalló 4-4.25m & Birm-521 & 17896 & 340 & $14 \mathrm{C}$ & Bone & $22,570-20,570$ & US & US & Bofinger and Davidson, 1977 \\
\hline Maltravieso A & Poz-30469 & 17930 & 100 & AMS & Charcoal & $21,630-21,270$ & $\mathrm{BA}$ & $\mathrm{BA}$ & Canals et al., 2010 \\
\hline Nerja $8 c$ & UBAR 98 & 17940 & 200 & $14 \mathrm{C}$ & Charcoal & $22,190-20,990$ & US & US & Jordá Pardo and Aura, 2009 \\
\hline Gorham's Cave III & Beta-184042 & 18440 & 160 & AMS & Charcoal & $22,370-22,120$ & US & US & Finlayson et al., 2006 \\
\hline Parpalló T-11 & OxA-22629 & 18510 & 100 & AMS & Bone & $22,700-21,780$ & BA & $\mathrm{BA}$ & This paper \\
\hline Gato 2 & GrA-22505 & 18650 & 140 & AMS & Charcoal & $22,800-22,160$ & AM & $\mathrm{AM} / \mathrm{BA}$ & Blasco and Rodanés, in press \\
\hline
\end{tabular}


Table 1 (continued)

\begin{tabular}{|c|c|c|c|c|c|c|c|c|c|}
\hline Site and level & Lab $\mathrm{Nr}$ & Date & SD & Method & Material & $\begin{array}{l}\text { CalAge BP (95\%) } \\
\{0=\text { AD } 1950\}\end{array}$ & Phase & $\begin{array}{l}\text { Phase } \\
\text { this paper }\end{array}$ & Reference \\
\hline Cendres XIII & Beta-118027 & 18750 & 130 & AMS & Charcoal & $22,860-22,380$ & US & US & Villaverde et al., 1999 \\
\hline Cendres XIII & Beta-118026 & 18920 & 180 & AMS & Charcoal & $23,250-22,410$ & US & US & Villaverde et al., 1999 \\
\hline B. de la Xemeneia & Beta-191695 & 18950 & 90 & AMS & Bone & $23,080-22,560$ & US & US & Mangado et al., 2010 \\
\hline Parpalló T-16 & OxA-22651 & 19020 & 100 & AMS & Bone & $23,230-22,590$ & US & US & This paper \\
\hline Ambrosio II. 2 & Gif-A-II.2 & 19170 & 190 & AMS & Charcoal & $23,630-22,310$ & US & US & Ripoll et al., 2006 \\
\hline Ambrosio II g & GifA 9883 & 19250 & 70 & AMS & Charcoal & $23,570-22,490$ & US & US & Ripoll et al., 2006 \\
\hline Ambrosio II.6 & Gif-A-II.6 & 19300 & 190 & AMS & Charcoal & $23,680-22,440$ & US & US & Ripoll et al., 2006 \\
\hline \multicolumn{10}{|c|}{ Other dates mentioned } \\
\hline Ambrosio VI & Gif-7277 & 16590 & 1400 & $14 \mathrm{C}$ & Charcoal & & MS & & Ripoll López, 1988 \\
\hline Beneito B2 & Ly-3596 & 16560 & 480 & $14 \mathrm{C}$ & $\mathrm{B}$ & & US & & Iturbe and Cortell, 1987 \\
\hline Malladetes III & $\mathrm{KN}-\mathrm{I} / 918$ & 16300 & 1500 & $14 \mathrm{C}$ & Charcoal & & US & & Fortea and Jordá, 1976 \\
\hline
\end{tabular}

mostly circular or oval section. During the earliest part of this horizon the majority of the Le Placard type points appear, as well as motifs made with a technique that closely resembles the pseudo-excise. Therefore, in the Badegoulian levels of Parpalló all the characteristics of the Cantabrian AM may be recognized (Figs. 2 and 3: 9-10).

Utrilla has recently suggested, based on the material and dates from Cueva del Gato (Aragón, Ebro valley), that Le Placard type bone points appear earlier in the Ebro valley (Gato -2 : 18.6 and $17.7 \mathrm{ka}{ }^{14} \mathrm{C} \mathrm{BP}$ ) and the Mediterranean region (cf. Parpalló 4-4,25m: $17.9 \mathrm{ka}{ }^{14} \mathrm{C} \mathrm{BP}$ ), compared to Cantabria (Castillo -8: $16.8 \mathrm{ka}{ }^{14} \mathrm{C} \mathrm{BP}$ and Rascaño -5 : $16.4 \mathrm{ka}{ }^{14} \mathrm{C} \mathrm{BP}$ ) (Table 1). The Ebro valley forms a natural passage for communication between the Cantabrian and Mediterranean regions (Utrilla et al., 2010).

- A Lower Magdalenian (LM) horizon with an important blade and bladelet component, similar to the Cantabrian LM. Up until now this facies has been better recorded in Meseta, Catalonia and the Ebro valley.

\section{Analysis of the radiocarbon series}

The original set of dates ranging from 19.5 to $14.5 \mathrm{ka}{ }^{14} \mathrm{C} \mathrm{BP}$ $(23,690-17,620$ cal BP) was critically reviewed in relation to their stratigraphic and archaeological contexts. Those which contradicted their stratigraphic position were rejected. This was the case with a large number of dates due to the fact that the Solutrean-Magdalenian "transition" coincides with a period during which there was extensive erosion. Similarly, dates from poorly defined archaeological contexts or those with only preliminary data were also excluded. Two dates from each level were selected and in those cases where more were available, the most recent and oldest and those with the least standard deviation were preferred. In general, only those dates with a standard deviation of less than 350 years were included, amounting to 44 in the Cantabrian region and 29 in the Mediterranean. The dates were calibrated using CalPal (Weninger and Jöris, 2004).

Table 1 lists the 73 selected dates together with relevant information. Given that there is not always agreement on the attribution of a dated context to a particular chrono-cultural phase, the table includes two columns. The first lists the attribution suggested by the original investigators of the site, while the second is based on a revised synthesis of the evidence.

A total of 39 dates were obtained using AMS and further 34 by conventional ${ }^{14} \mathrm{C}$. The proportion of the two methods changes in relation to geographic regions and chrono-cultural phases. More than $60 \%$ of the selected dates from the Cantabrian region were obtained using conventional ${ }^{14} \mathrm{C}$, compared to only $24 \%$ of those from the Mediterranean region. Comparison of the different cultural facies points to the LM as having more dates available (34, $43.8 \%)$, followed by the US $(22,38.5 \%)$ and finally the AM (17, 23.3\%). Moreover, most of the conventional ${ }^{14} \mathrm{C}$ dates correspond to the US in the Mediterranean region and to the LM in the Cantabrian. Such differences reflect the variable pace of research in different regions as well as regional research "traditions".

The selected dates place the palaeoclimatic context of the Solutrean-Magdalenian transition between Heinrich Events 2 and 1 and during the climate phases GI 2 and GS 2. The chronological data were correlated with high resolution proxies, the ${ }^{18} \mathrm{O}$ GISP2 Hulu Age Model (Grootes et al., 1993; Meese et al., 1994; Wang et al., 2001) and the SST MD95-2043 from the Alboran Sea (Cacho et al., 2001).

The 73 selected dates may be grouped into three broad chronocultural units, the Upper Solutrean (US), the Archaic Magdalenian (AM) or Badegoulian (BA) and the Lower Magdalenian (LM). Besides calibration using CalPal 2007 Hulu (Weninger et al., 2012 online), one curve was obtained for each region and different curves for each one of the three facies (Fig. 4).

The regional curves show the succession of archaeological phases as described above (US-AM/BA-LM). In the Cantabrian region there is more of an overlap while in the Mediterranean there is a hiatus of approximately 700 years between the AM/BA and the LM. The "transitional" phases unfortunately correspond with episodes of instability in the calibration curves, probably related to a general fluctuation in atmospheric ${ }^{14} \mathrm{C}$. In addition there are the erosion processes discussed previously (Hoyos, 1994; Rasilla Vives, 1994; Aura Tortosa, 1995; Aura et al., 2006).

Table 2 summarizes the data which point to regional differences, mostly for the end of the US and the central horizon (AM/BA). Probability curves for the LM are practically coincident despite the fact that this phase is poorly documented in the Mediterranean region.

The data suggest that the US ended earlier in Cantabria than in the Mediterranean region. This is because various assemblages from the former region, listed as Solutrean in the literature, have been attributed to the AM, thus widening the probability curve for this phase by up to 2700 cal years. The contexts which make up this phase are characterized by local raw material use, the production of flakes, an increase in backed bladelets, tools of archaic appearance and a few raclettes, and the virtual absence $(<3 \%)$ of Solutrean tool types (Straus, 1975; Straus and Clark, 1986; Corchón, 1994, 1999; Rasilla Vives, 1994). The phase is also characterized by the presence of bone points of rounded or flat section and long basal bevel, and the use of the pseudo-excise decoration technique. Finally, in the Cantabrian region there is an overlap of approximately 600 calibrated years between the AM and LM curves (Fig. 4).

In the Mediterranean region, the probability curve for US dates is a millennium longer than in Cantabria. There are dates that could potentially extend the end of the US until approximately $21 \mathrm{ka} c a l$ 

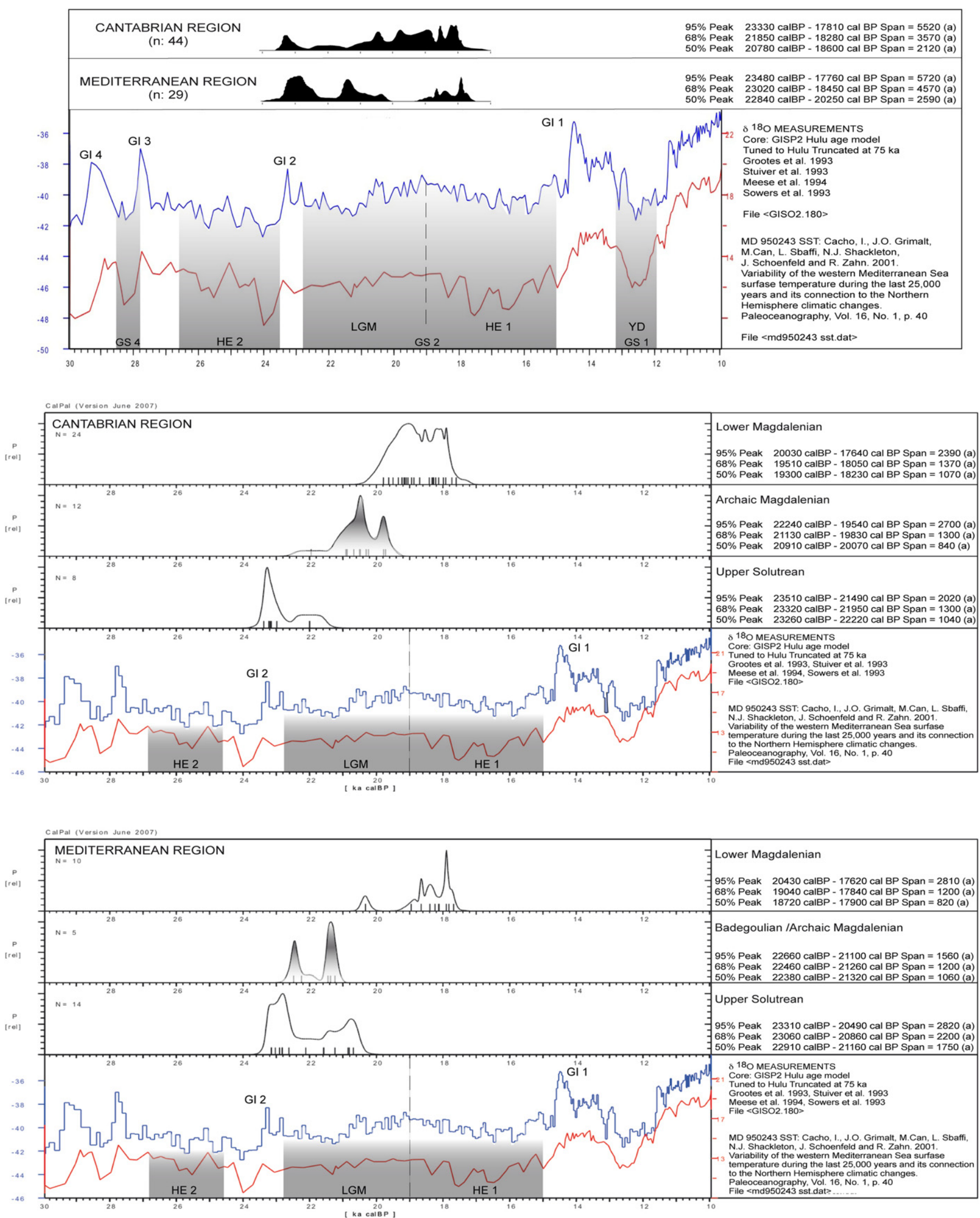

Fig. 4. Cumulative probability curve of the valid radiocarbon dates from the Cantabrian and Mediterranean regions of Iberia. For calibration CalPal 2007 Hulu (Weninger et al., 2012) was used. Top: Curves for the Cantabrian and the Mediterranean regions showing the erosional discontinuities mentioned in the text. Center: The curves for the Cantabrian region arranged in each one of the chrono-cultural phases (US, AM and LM). Bottom: Curves for the Mediterranean region arranged in each one of the three chrono-cultural phases (US, BA and LM). Palaeoclimate proxies: ${ }^{18}$ O GISP2 Hulu Age Model (Grootes et al., 1993; Meese et al., 1994; Wang et al., 2001) and SST MD95-2043 obtained in the Alboran Sea (Cacho et al., 2001). 
Table 2

Calibrated chronology of the three major chrono-cultural phases.

\begin{tabular}{|c|c|c|}
\hline & Cantabrian region & Mediterranean region \\
\hline Lower Magdalenian & (95\%) $20,030-17,640$ cal BP & (95\%) 20,430-17,620 cal BP \\
\hline Archaic Magdalenian/Badegoulian & (95\%) $22,240-19,540$ cal BP & (95\%) $22,660-21,100 \mathrm{cal} \mathrm{BP}$ \\
\hline Upper Solutrean & (95\%) $23,510-21,490$ cal BP & (95\%) $23,310-20,490$ cal BP \\
\hline
\end{tabular}

BP. However, these were not included in this synthesis as they include bulk bone samples dated to around $16500 \mathrm{ka}{ }^{14} \mathrm{C} \mathrm{BP}$ with standard deviation values greater than 350 years (Malladetes, Beneito or Ambrosio). Half of the US dates were obtained by conventional ${ }^{14} \mathrm{C}$ and these are the most recent, while new AMS dates place the end of the US at approximately $20.5 \mathrm{ka}$ cal BP (Table 1).

The BA in the Mediterranean region is poorly-dated. However, new dates have recently become available, including one so far unpublished, that places the basal levels of the Badegoulian at Parpalló at 22.7 and $21.8 \mathrm{ka}$ cal BP. This date (OxA-22629), is being cross-checked at present with further samples. At Gato -2 , an AM/BA context with a point with Le Placard decoration was dated to between 22.8 and $21 \mathrm{ka}$ cal BP. At Maltravieso (Extremadura), a site near Portugal and thus located closer to the Atlantic than to the Mediterranean coastal region, two dates (21.6 and $21.2 \mathrm{ka}$ cal BP) were obtained for an poorly-defined assemblage characterized by the use of local raw materials, flakes and one raclette (Canals et al., 2010).

\section{The US-BA transition at Parpalló: analysis of the lithic and bone toolkit}

Parpalló is a reference sequence for the Palaeolithic of SW Europe. Excavated by L. Pericot between 1928 and 1931, the site contains evidence for successive human occupation from the Gravettian to the Magdalenian with harpoons. The Solutrean Magdalenian succession was established by Pericot (1942) at approximately $4 \mathrm{~m}$ from the top in a $9.5 \mathrm{~m}$ deep trench. Even at that time it was clear that there were difficulties in differentiating the layers with US material from those with Magdalenian/Badegoulian artifacts. The analysis of the graphic documents and artefacts from the "talus" sector confirmed these difficulties, but has allowed the US - BA succession to be placed at approximately $3.50 \mathrm{~m}$ (Aura Tortosa, 1995, 2007).

Data for lithic production within levels directly related to the US BA succession are now available, allowing comparison with levels bracketed to between 4.25 and $4.00 \mathrm{~m}, 4.00-3.75 \mathrm{~m}$ and $3.75-3.50 \mathrm{~m}$. The review of the AM/BA lithic assemblage is part of a wider project comparing processes at Cantabrian and Mediterranean sites. However, it has recently been claimed by Banks et al. (2011, pp. 361) that there is no convincing evidence for a Badegoulian presence in the Iberian Peninsula. The first results of the analysis of lithic production during the transition period and in relation to changes observed in the bone industries are presented below.

\subsection{Lithic production}

The lithic industries of the part of the Parpallo sequence included in this analysis comprise approximately 30,000 pieces, of which 14,598 have been studied. The rest of the materials do not provide well defined technological or typological information (decortication flakes, atypical flakes, debris, fragments, altered pieces and others). There is an extensive list of descriptors for the analysis of transitional lithic industries. These may be organized in 6 broad categories in which cores, blanks and retouched pieces are grouped:
A) Blade production for blanks to produce Mediterranean shouldered points and the few foliate points. Most of the evidence for thermal (fire) treatment of blanks and cores is related to these artifacts.

B) Blade blank production for end-scrapers, burins, truncations and backed blades. The identification of this production may be related in part to the use of different raw materials from those employed in group $\mathrm{A}$.

C) Bladelet production for the manufacture of Mediterranean shouldered points, backed bladelets and points.

D) Short, broad blades for the manufacture of domestic tools (short end-scrapers, side-scrapers, pieces with simple and semi-abrupt retouch).

E) Production from indeterminate and multifaceted cores. This undifferentiated flake production using soft hammer direct percussion may have had various aims, classic blade percussion, production of blanks with a laminar tendency and also flake production. Simple retouched pieces often have use wear traces, while there are also some notches and some splintered pieces.

F) Production termed "Badegoulian" that groups together discoidal-facial-Levallois percussion (Bracco et al., 2003; Cretin et al., 2007), core-scrapers (Bodu, 2005), dorsal front cores (Ducasse and Langlais, 2007) and core-burins (Le Brun-Ricalens and Brou, 2003). Discoidal-facial-Levallois cores, described by Bracco et al. (2003) and Crétin et al. (2007) provided blanks for short end-scrapers, retouched micro-tools, retouched flakes and the first raclettes (Fig. 5). All the other core types have preserved but a few bladelets, possibly as a result of the recovery techniques used during the 1928-1932 excavation campaigns at Parpalló (Zilhão, 1997; Straus et al., 2008).

The changes recorded in these six groups provide evidence for the transformation of technoeconomic structures of the US. The shaping of new strategies in lithic production is more obvious when comparing the lower and upper levels of the part of the Parpalló sequence presented here. Analysis points to a continual decline in blade production and the increase of undifferentiated, Badegoulian and short-wide blade blanks. These comprise $40 \%$ of lithic production in level $3.75-3.50 \mathrm{~m}$, compared to $11 \%$ in level $4.25-4.00 \mathrm{~m}$. This tendency becomes more marked in overlying levels (Fig. 6).

\subsection{Bone and antler production}

Bone and antler industries increase in parallel with the changes in lithic production. However, there are no data concerning the techniques that were used to prepare the blanks (grooving vs. debitage by percussion) (Allain et al., 1974; Adán Àlvarez, 1994; Averbouh and Pétillon, 2011).

At Parpalló, the bone industry of levels between 4.25 and $3.75 \mathrm{~m}$ is dominated by round and flat cross-section pieces of two main types, bi-pointed and single basal bevel points (Pericot, 1942). Bi-pointed pieces with polygonal cross-sectional bases, the first points with single bevel and two Le Placard sagaies derive from US level (4.25-4.00 m). Points with single basal bevel, with oblique marked incisions appear frequently in the overlying part of the 

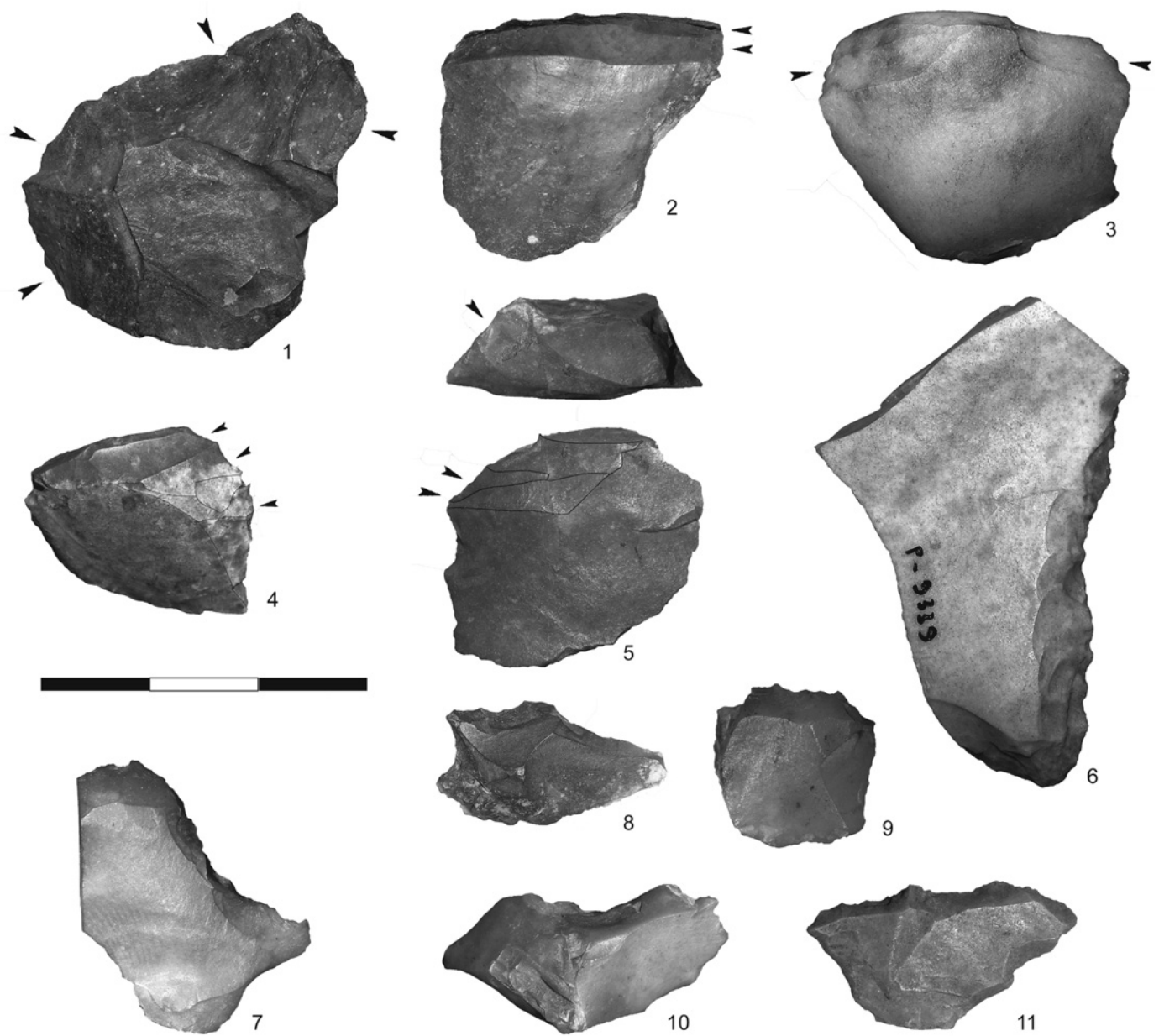

11

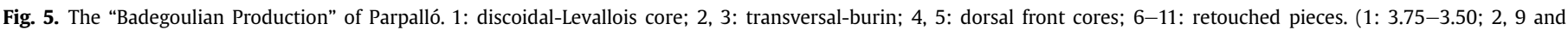
11: sector L 3.75-3.50; 3: sector CE 4.25-4.00; 5: sector CE 4.00-3.75; 4, 6, 7, 8 and 10: sector CE 3.75-3.50).

\begin{tabular}{|c|c|c|c|c|c|c|c|c|c|c|c|c|c|c|c|c|c|c|}
\hline & & & (A) & (B) & (C) & (D) & (E) & (F) & (A) & (B) & (C) & (D) & (E) & (F) & & \multirow{2}{*}{$\begin{array}{l}\text { (F) } \\
\text { 'BADEGOULIAN } \\
\text { PRODUCTION' }\end{array}$} & $\begin{array}{l}\text { - Core-scrapers } \\
\text { - Dorsal front-cores } \\
\text { - Core-burin }\end{array}$ & $\begin{array}{l}\text { Micro- } \\
\text { bladelets }\end{array}$ \\
\hline 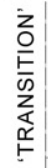 & 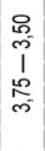 & Retouched tools & 35 & 671 & 13 & 35 & 267 & 93 & & & & & & & $\begin{array}{c}0 \\
1 \\
0 \\
0\end{array}$ & & \multicolumn{2}{|c|}{$\begin{array}{l}\text { - Discoidal-facial-Levallois: } \\
\text { Short end-scrapers } \\
\text { Retouched micro-tools } \\
\text { Retouched flakes } \\
\text { First raclettes }\end{array}$} \\
\hline \multirow{5}{*}{ 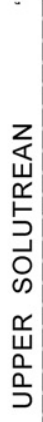 } & \multirow{2}{*}{$\begin{array}{l}2 \\
2 \\
0 \\
1 \\
0 \\
\sigma \\
\sigma\end{array}$} & & & & & & & & & & & & & & & (E) UNDIFFERENCIATED & \multicolumn{2}{|c|}{$\begin{array}{l}\text { Simple retouched pieces } \\
\text { Notches } \\
\text { Splintered pieces }\end{array}$} \\
\hline & & Total: 4166 & & & & & & & & & & & & & & & \multicolumn{2}{|l|}{$\begin{array}{l}\text { End-scrapers } \\
\text { Side-scrapers } \\
\text { Pieces with } \\
\text { semi-abrupt retouch }\end{array}$} \\
\hline & \multirow{3}{*}{ 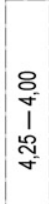 } & & & & & & & & & & & & & & & (C) & \multicolumn{2}{|c|}{$\begin{array}{l}\text { Backed bladelets } \\
\text { Mediterranean shouldered points }\end{array}$} \\
\hline & & Debitage & 81 & 1921 & 161 & 4 & 87 & 88 & & & & & & & 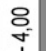 & & \multirow{2}{*}{\multicolumn{2}{|c|}{\begin{tabular}{|l|} 
End-scrapers \\
Burins \\
Truncations \\
Backed blades
\end{tabular}}} \\
\hline & & Retouched tools & 232 & 487 & 4 & 1 & 151 & 1 & & & & 1 & & & 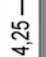 & $\begin{array}{l}\text { (B) } \\
\text { BLADES / } \\
\text { BLADELETS }\end{array}$ & & \\
\hline
\end{tabular}

Fig. 6. Distribution of the lithic productions that correspond to the US-BA 'transition' at Parpalló. The column to the right includes retouched artifacts associated to each one of the lithic productions. 
sequence (4.00-3.75 m). Most of Le Placard sagaies together with bone points with wide, convex single bevels covering more than a third of their length (Pericot, 1942), were concentrated in the upper level $(3.75-3.50 \mathrm{~m}$ ) although they are also present in the overlying layers (3.50-3.25 m). The engraved representation of an ibex, Capra pyrenaica, using a technique similar to pseudo-excise decoration, was recovered in the upper part of the sequence (Pericot, 1942, fig 76.6). The same technique was documented at Volcán del Faro on a thick piece of round section and with a rounded base, which was also associated with raclettes (Fig. 3: 7).

\section{Discussion}

The archaeological record in the two regions of Iberia discussed here is essentially known from stratified caves and rock shelters. The understanding of lithic production strategies in the Cantabrian region is insufficient to allow a discussion of the degree of continuity and transformation of technoeconomic strategies between the US and the AM. This is even more so for the so-called transitional facies that appear better represented in Asturias (Las Caldas, La Riera, possibly Cueto de la Mina and El Cierro). In these assemblages there are certain characteristics, including local raw material use and the presence of tools with archaic features, which show similarities with Parpalló (with low frequencies of limestone and quartzite) and the French Badegoulian (Bodu et al., 2007a).

The presence of Solutrean points in AM assemblages is not exclusive to the Cantabrian region sites; it is also described at other sites such as Abri Fritsch, Laugerie Haute, Badegoule and Parpalló. The presence of these objects may be related to sedimentary processes, in which case separate taphonomic analysis at each site is required. Nonetheless, continuity of occupation may also be implied by their presence.

The data from Parpalló permit a preliminary evaluation of changes in lithic production between the US and BA, without however implying a single model of technoeconomic transformation. A few Solutrean pieces (shouldered points and bifacial solutrean flakes) are still recorded in level $3.75-3.50 \mathrm{~m}$ representing $0.9 \%$ of 3433 retouched pieces and $2.8 \%$ of all debitage. Moreover, a significant decline in laminar production is recognized, followed by an increase in undifferentiated production of short flakes and elements grouped as "Badegoulian" (flake production, microbladelet and microflake production from carinated cores, core-burins and transversal burins).

The data indicate that the evolutionary inertia of the lithic production categories (A, B and C) lasts longer than the actual tool types (Mediterranean solutrean points and foliate points) (Fig. 6), a characteristic also observed in other periods (Tiffagom, 2006b, pp. 72). This transformation process suggests the following two hypotheses:

1) The changes observed in the frequency of lithic elements between 4.25 and $3.50 \mathrm{~m}$ at Parpalló may have resulted from post-depositional processes. Analysis of possible inter- and intra-stratigraphic refitting would be useful for the evaluation of this hypothesis. However, no data is yet available.

2) The co-existence of various traits may indicate the presence of a formative Badegoulain phase with US-BA elements that in turn would suggest a transition rather than a simple substitution process. Antecedents of such a model could be suggested for describing the transformation that took place in lithic production during the Mediterranean US (Tiffagom, 2006).

These changes observed in lithic production may also be related to the intensity of the activities performed with chipped stone artifacts. The description of tools with an "archaic" appearance and the presence of evidence for rejuvenation and recycling is commented upon with reference to the BA industries (Aura Tortosa, 1995). Correlation of these characteristics with the duration of occupation and settlement systems should be assessed (Barton, 1991; Bamforth and Bleed, 1997; Straus et al., 2008). Moreover, these characteristics are documented in both regions despite their significant ecological differences. This suggests that the observed convergence in lithic and bone/antler production may be explained by regional scale connections between groups.

Finally, in the light of the new radiocarbon data, the beginning of the AM/BA in the Mediterranean region appears to be dated as early as the Badegoulian in France (Crétin et al., 2007; Ducasse, 2010). In this case the duration of the Upper Solutrean would be shorter and the dates after ca. 20 cal BP for the LM of the Spanish Mediterranean region would be compatible with the new data. However, these should be treated with caution (Aura Tortosa and Jordà Pardo, in preparation).

\section{Conclusions}

The diagnostic artifacts types repeatedly used in this paper are invasively retouched Solutrean points, Mediterranean backed shouldered points, "archaic" tools, raclettes, sagaies with circular section, single basal bevels, Le Placard type decoration and pseudoexcise decoration. In Iberia the association and stratigraphic location of these elements provide regional links with areas to the north of the Pyrenees (Bodu et al., 2007b). In the Cantabrian region, Le Placard bone points appeared until recently, to be associated with the AM facies at Rascaño - 5 (Utrilla, 2006). However, at Llonín these elements are associated with other diagnostics such as the use of local raw materials, raclettes and the pseudo-excise technique (Fortea et al., 2004). Some of these elements are also present at La Riera, Cueto de la Mina (Fig. 3: 4-6). In the Mediterranean area, such bone points may be found at the base of the BA, but with possible intrusion from US levels at Parpallo. In the Ebro valley the dates from Gato -2 antedate the data from the Cantabrian region (Utrilla et al., 2010). Therefore, when the US-AM/BA succession is assessed on the basis of artifact "substitution" patterns, it is characterized by regional variability although with some shared elements.

These changes coincided with significant increases in bone points that should not be considered a Magdalenian feature, but rather a Badegoulian one. The distribution of bi-points and thick pieces, Breuil's "gros ciseaux et lissoirs ornés" (1912, Figs. 21 and 22 ), the generalization of single basal bevel points of round and oval section, Le Placard types, and the pseudo-excise technique provide additional evidence for contact between groups in the Cantabrian region, the Ebro Valley and the Mediterranean region. It is improbable that with so many characteristics in common, contacts between different regions did not exist (Sauvet et al., 2008, pp. 39). The simplest explanation for these similarities is that after 22.5-22 ka cal BP, transformation processes took place in much of the previous "Solutrean territory" in these regions.

In Iberia there is no agreement concerning the naming of the technoeconomic process that took place during the GS 2. However, the AM assemblages of the Cantabrian region and the BA of the Mediterranean region share many key attributes.

\section{Acknowledgements}

The results presented in this paper were obrtained within the framework of the Research Project HAR2008-03005: La Transición Solutrense - Badeguliense - Magdaleniense en la Península ibérica (19,000-15,000 años BP) contrastación de los datos del Cantábrico occidental (Asturias) y del Mediterráneo central (Valencia) (SOBA$\left.M A^{\mathrm{p} ?}\right)$. Ministerio de Ciencia y Tecnología, Gobierno de España. 
We are grateful to the SIP-Museu de Prehistòria de València for giving us permission to study the materials from Cova del Parpalló and Volcán del Faro. Rachel Wood and Tom Higham (University of Oxford, ORAU) applied numerous tests aiming to obtain the best samples for dating the Solutrean-Badegoulian transition in Iberia. We would like to express our gratitude to Maria Ntinou for reviewing and L.G. Straus for correcting the English text. We started this project with Javier Fortea Pérez. He will always be remembered.

\section{References}

Adán Álvarez, G., 1994. El material óseo del Solutrense Peninsular: Secuencia, soporte óseo, métodos de trabajo y tipología. Monográfico El Solutrense en la Península Ibérica, Férvedes 1, 159-174.

Aguirre Ruíz de Lopegui, M., 1999. Antoliñako Koba (Gautegiz, Arteaga). II Campaña de Excavaciones, vol. 98. Arkeiokuska, pp. 99-102.

Allain, J., Fritsch, R., Rigaud, A., Trotignon, F., 1974. Le débitage du bois de renne dans les niveaux à raclettes du Badegulien de l'Abri Fritsch et sa signification. In: Camps-Fabrer, H. (Ed.), Ier. Colloque International Abbaye de Sénnanque, pp. 67-71.

Altuna, J., 1972. Fauna de mamíferos de los yacimientos prehistóricos de Guipúzcoa. Munibe 24. San Sebastián.

Altuna, J., Merino, J.M., 1984. El Yacimiento prehistórico de la Cueva de Ekaín. Sociedad de Estudios Vascos, Sociedad de Ciencias Aranzadi, San Sebastián.

Altuna, J., Baldeón, A., Mariezkurrena, K., 1985. Cazadores Magdalenienses de Erralla (Cestona, País Vasco). Sociedad de Ciencias Aranzadi, San Sebastián Munibe 37, $1-206$.

Aparicio, J., 2003. El paleomesolítico valenciano: Cova del Volcán del Faro: memoria de las excavaciones e inventario del material. Real Academia de Cultura Valenciana, Sección de Prehistoria y Arqueología, Valencia.

Aubry, T., Almeida, M., Chehmana, L., Thiennet, H., Walter, B., 2007. De la fin du Solutréen au Magdalénien moyen dans les vallées de la Claise et de la Creuse. Bulletin de la Société préhistorique française 104, 699-714.

Aura Tortosa, J.E., 1995. El Magdaleniense Mediterráneo: la Cova del Parpalló (Gandía, Valencia). Trabajos Varios del SIP, 91. Museu de Prehistòria, Valencia.

Aura Tortosa, J.E., 2007. Badegouliens et Magdaléniens du versant méditerranéen espagnol. Bulletin de la Société préhistorique française 104, 809-824.

Aura Tortosa, J.E., Jordá Pardo, J.F. Cronología radiocarbónica y procesos culturales: la transición Solutrense-Badeguliense-Magdalenisnes en la región mediterránea española. In: Ripoll, S., Jordá, J., Múñoz, F. (Eds.), Pre-Actas del Congreso Internacional "El Solutrense". Centenario de las excavaciones en la Cueva de Ambrosio, UNED, Madrid, pp.16-17.

Aura Tortosa, J.E., Jordá Pardo, J.F., Fortea, F.J., 2006. La Cueva de Nerja (Málaga, España) y los inicios del Solutrense en Andalucía. Zephyrus 59, 73-94.

Averbouh, A., Pétillon, J.-M., 2011. Identification of "debitage by fracturation" on reindeer antler: case study of the Badegoulian levels at the Cuzoul de Vers (Lot, France). In: Baron, J., Kufel-Diakowska, B. (Eds.), Written in Bones. Studies on Technological and Social Contexts of Past Faunal Skeletal Remains. Uniwersytet Wroclawski, Institute Archeologii, Wroclaw, pp. 41-51.

Bamforth, D.B., Bleed, P., 1997. Technology, flaked stone technology, and risk. In: Barton, C.M., Clark, G.A. (Eds.), Rediscovering Darwin: Evolutionary Theory and Archaeology Explanation. Archaeological Papers of the American Anthropological Association $\mathrm{N}^{\circ}$ 7, Arlington, pp. 109-139.

Banks, W.E., Zilhão, J., d'Errico, F., Kageyama, M., Sima, A., Ronchitelli, A., 2009. Investigating links between ecology and bifacial tool types in western Europe during the Last Glacial Maximum. Journal of Archaeological Science 36, 2853-2867.

Banks, W.E., Aubry, Th, d’Errico, F., Zilhão, J., Lira-Noriega, A., Townsed Peterson, A. 2011. Eco-cultural niches of the Badegoulian: unraveling links between cultura adaptation and ecology during the Last Glacial Maximum in France. Journal of Anthropological Archaeology 30, 359-374.

Barandiarán, I., 1973. Arte Mueble del Paleolítico Cantábrico. Monografías Arqueológicas XIV. Zaragoza.

Barandiarán, I., 1988. Datation C14 de l'art mobilier magdalénien cantabrique. Bulletin de la Société Préhistorique de l'Ariège 43, 63-84.

Barton, C.M., 1991. Retouched Tools: fact or fiction? Paradigms for interpreting chipped stone. In: Clark, G.A. (Ed.), Perspectives in Prehistory Paradigmatic Biases in Circum-Mediterranean Hunter-Gatherer Research. University of Pennsylvania Press, Philadelphia, pp. 143-163.

Barton, C.M., Riel-Salvatore, J., Anderies, J.M., Poescu, G., 2011. Modelling human ecodynamics and biocultural interactions in the Late Pleistocene of Western Eurasia. Human Ecology. doi:10.1007/s10745-011-9433-8.

Bergadà, M.M., 1998. Estudio geoarqueológico de los asentamientos prehistóricos del Pleistoceno Superior y el Holoceno inicial en Catalunya. BAR Internationa Series, vol. 742. Oxford.

Blasco, M.F., Rodanés, J.M. Las fases de ocupación de la Cueva del Gato -2 (Épila, Zaragozza), Salduie, 9, 311-334.

Bodu, P., 2005. Le gisement de Lailly (Yonne) une chaîne opératoire inedited au Paléolithique supérieur? ou un procédé de fabricaion d'éclats-supports pour nucleus à lamelles (grattoirs carénés) au sud du Bassin parisien, Productions lamellaires attribuées à l'Aurignacien: Chaînes opératoires et perspectives technoculturelles, XIVe congres de l'UISPP, Liège 2-8 septembre 2001, Luxembourg. Archéologiques 1, 297-310.

Bodu, P., Chehmana, L., Cretin, C., Ducasse, S., Langlais, M., 2007a. Le dernier Maximum glaciaire et après... en France et en Espagne, Synthèses régionales et reflexions autour de la diversité des cultures materielles de 19000 à $14000 \mathrm{BP}$ Actes de la Table Ronde Séance de la Société Préhistorique Française. Maison de la Recherche- Université de Toulouse-le-Mirail (9-10-2006). Bulletin de la Société préhistorique Française 104 (4), 655-824.

Bodu, P., Chehmana, L., Debout, G., 2007b. Le Badegoulien de la moitié nord de la France. Un état des connaissances. Bulletin de la Société préhistorique Française 104 (4), 661-679.

Bofinger, E., Davidson, I., 1977.. Radiocarbon age and depth: a statistical treatment of two sequences of dates from Spain. Journal of Archaeological Science 4, 231-243.

Bosselin, B., Djindjian, F., 1999. Une révision de la séquence de la Riera (Asturies) et la question du Badegoulien Cantabrique. Bulletin de la Société préhistorique française 96 (2), 153-173.

Bracco, J.P., Morala, A., Cazals, N., Cretin, C., Ferullo, O., Faourloubey, Ch, Lenoir, M. 2003. Peut-on parler de débitage discoïde au Magdalénien Ansíen/Badegoulien? In: Peresani, M. (Ed.), Discoid Lithic Technology. Advances and Implications BAR-International Series, vol. 1120, pp. 83-115 Oxford.

Breuil, H., 1912. Les subdivisions du Paléolithique supérieur et leur signification. In: Congrès International d'Anthropologie et d'Archéologie Préhistoriques. Compte Rendu de la XIVe session, Genève, (1937, 2nd Ed).

Cheynier, A., 1939. Le Magdalénien primitif de Badegoule: niveaux à raclettes. Bulletin de la Société préhistorique française 36, 354-396.

Cheynier, A., 1951. Les industries protomagdaléniennes. Bulletin de la Société préhistorique française 48, 189-192.

Cacho, I., Grimalt, J.O., Canals, M., Sbaffi, 1., Shackleton, N.J., Schönfeld, J., Zahn, R., 2001. Variability of the western Mediterranean Sea surface temperature during the last 25.000 years and its connection with the Northern Hemisphere climate changes. Paleoceanography 16 (1), 40-52.

Cacho, C. Martos, J.A., Jordá Pardo, J.F. Yravedra, J. Avezuela, B., Valdivia, J. Martin, I., 2010. El Paleolítico superior en el interior de la Península Ibérica. Revisión crítica y perspectivas de futuro. In: Mangado, X. (Ed.), El Paleolítico Superior Peninsular. Novedades del siglo XXI. SERP, Universitat de Barcelona,, Barcelona, pp. 115-136.

Canals, A., Rodriguez, A., Peña, L., Mancha, E., García-Díez, M., Bañuls, S., Euba, I., López, J.M., Barrero, N., Bermejo, I., García, F.J., Mejías, D., Modesto, M., Morcillo, A. Aranda, V., Carbonell, E., 2010. Nuevas aportaciones al Paleolítico superior del suroeste peninsular: la cueva de Maltravieso, más allá del santuario extremeño de las manos. In: Mangado, X. (Ed.), El Paleolítico Superior Peninsular. Novedades del siglo XXI. SERP, Universitat de Barcelona, Barcelona, pp. 199-218.

Cazals, N., Bracco, J.P., 2007. Quelles relations de part et d'autre des Pyrénées durant le Magdalénien? In: Cazals, N., González-Urquijo, J., Terradas, X. (Eds.), Fronteras naturales y fronteras culturales en los Pirineos prehistóricos. Universidad de Cantabria, Santander, pp. 125-142.

Conde de la Vega del Sella, 1916. Paleolítico de Cueto de la Mina (Asturias). Comisión de Investigaciones Paleontológicas y Prehistóricas. Memoria 13. Museo Nacional de Ciencias Naturales, Madrid.

Corchón, Ma.S., 1981. La cueva de Las Caldas, San Juan de Priorio (Oviedo). Excavaciones Arqueológicas en España 15, Madrid.

Corchón, Ma.S., 1994. Arte mobiliar e Industria ósea solutrense en la Cornisa cantábrica. Monográfico El Solutrense en la Península Ibérica, Férvedes 1,131-148.

Corchón, Ma.S., 1999. Solutrense y Magdaleniense del oeste de la Cornisa Cantábrica: dataciones 14C (calibradas) y marco cronológico. Zephyrus 52, 3-32.

Corchón, Ma.S., 2005. El Magdaleniense en la Cornisa Cantábrica: nuevas investigaciones y debates actuales. In: Bicho, N. (Ed.), O Paleolítico, Actas do IV Congresso de Arqueologia Peninsular. Universidade do Algarve, Faro, pp. 15-38. Promontoria Monografica 02.

Cretin, C., 2007. Arrêt sur le Badegoulien: Historique, état de la question et perspectives. In: Évin, J. (Ed.), Un Siècle de Construction du discours scientifique en Préhistoire, Des Idées d'hier. Actes du 26eme Congrès Préhistorique de France, Avignon 2004, vol.1. Société préhistorique française, Paris, pp. 367-378.

Cretin, C., Ferullo, O., Fourloubey, C., Lenoir, M., Morala, A., 2007. Le Badegoulien du nord de l'Aquitaine: de noveaux moyens de lecture. Bulletin de la Société préhistorique française 104 (4), 715-734.

Delibrias, G., Romain, O. La Hasif, G., 1987. Datation par le méthode du carbone 14 du remplissage de la grotte de l'Arbreda, Cypsela VI, pp. 133-135.

Ducasse, S., 2010. La " parenthèse » badegoulienne: Fondements et statut d'une discordance industrielle au travers de l'sanalyse techno-économique de plusieurs ensembles lithiques méridionaux du Dernier Maximum Glaciaire. Unpublished Ph.D. dissertation, University of Toulouse, Toulouse, France.

Ducasse, S., Langlais, M., 2007. Entre Badegoulien et Magdalénien, nos coeurs balancent... Approche critique des industries lithiques du Sud de la France et du Nord-Est espagnol entre 19000 et 16500 BP. Bulletin de la Société préhistorique française 104 (4), 771-785.

Finlayson, C., Giles Pacheco, F., Rodríguez-Vidal, J., Fa, D., Gutierrez López, J.-M., Santiago Pérez, A., Finlayson, G., Allue, E., Baena Preysler, J., Cáceres, I., Carrión, J., Fernández Jalvo, Y., Gleed-Owen, C., Jimenez Espejo, F., López, P., López Sáez, J.-A., Riquelme Cantal, J.-A., Sánchez Marco, A., Giles Guzman, F., Brown, K., Fuentes, N., Valarino, C., Villalpando, A., Stringer, C.B., Martinez Ruiz, F., Sakamoto, T., 2006. Last survival of Neanderthals at the southernmost extreme of Europe. Nature 443, 850-853. 
Fortea, J., 1989. El Magdaleniense medio en Asturias, Cantabria y el País Vasco. Actes du Colloque de Mayence (1987) Le Magdalénien en Europe. Eraul, vol. 38. 419-440.

Fortea Pérez, J., 2005. La plus ancienne production artistique du Paléolithique iberique. Simposio Pitture Paleolitiche nelle Prealpi venet. In: e. Grotta di Fumane e Riparo Dalmieri (Verona, 2003). Prehistoria Alpina $\mathrm{N}^{\circ}$ speciale, pp. 53-65.

Fortea, J., Jordá Cerdá, F., 1976. La Cueva de les Mallaetes y los problemas del Paleolítico superior del Mediterráneo español. Zephyrus 26-27, 129-166.

Fortea, J., Fullola, J.-M., Villaverde, V., Davidson, I., Dupré, M., Fumanal, M.-P., 1983. Schéma paleoclimatique, faunique et chronostratigraphique des industries à bord abattu de la région méditerranéenne espagnole. Rivista di Scienze Preistoriche 38 (1-2), 21-67.

Fortea, J., Rasilla, M., de la, Rodriguez, V., 1995. La Cueva de Llonin (Llonin, Peñamellera Alta). Campañas de 1981 a 1994. Excavaciones Arqueológicas en Asturias 3, 33-44. 1991-1994.

Fortea, J., Rasilla, M., de la, Rodríguez, V., 2004. L'art pariétal et la séquense archéologique paléolithique de la grotte de Llonín (Peñamellera Alta, Asturias, Espagne). Préhistoire, Arts et Sociétes LIX, pp. 7-29.

Fortea, J., Rasilla, M., de la, Rodriguez, V., 2007. La Cueva de Llonín (Llonín, Peñamellera Alta). Campañas de 1999 a 2002. Excavaciones Arqueológicas en Asturias 5, 77-86.

Fullola Pericot, J.M., 1979. Las industrias líticas del Paleolítico Superior Ibérico. Trabajos Varios del SIP, 60. Museu de Prehistòria, València.

Fumanal, Mạ.P., 1986. Sedimentología y Clima en el Pais Valenciano. In: Las Cuevas habitadas en el Cuaternario reciente. Trabajos Varios del SIP, vol. 83. Museu de Prehistòria, Valencia.

González-Echegaray, J., Barandiarán, I. (Eds.), 1981, Excavaciones en la Cueva del Rascaño (Santander), vol. 3. Monografías del Centro de Investigación y Museo de Altamira, Madrid.

González-Echegaray, J., 1996. Le Magdalènien Inferieur Cantabrique et ses reelations avec le Périgord. Actes du $118^{\mathrm{e}}$ Congrés National des Sociétés Historiques et Scientifiques (Pau, 1993). In: Delporte, H., Clottes, J. (Eds.), Pyrénées préhistoriques - Art et sociétés. C.T.H.S, Paris, pp. 279-282.

González Morales, M.R., 1990. El Abrigo de Entrefoces (1980-83). Excavaciones Arqueológicas en Asturias 1, 29-36.

González Morales, M.R., Straus, L.G., 2009. Extraordinary Early Magdalenian finds from el Mirón Cave, Cantabria (Spain). Antiquity 83, 267-281.

Grootes, P.M., Stuiver, M., White, J.W.C., Johnsen, S., Jouzel, J., 1993. Comparison of Oxygen Isotope records from the GISP2 and GRIP Greenland Ice Core. Nature 366, 552-554.

Hoyos, M., 1994. Características sedimentokársticas y paleoclimáticas de los interestadios de Laugerie-Lascaux en la Cornisa Cantábrica. Monográfico El Solutrense en la Península Ibérica, Férvedes 1, 21-37.

Iturbe, G., Cortell, E., 1987. Las dataciones de Cova Beneito y su interés para el Paleolítico Mediterráneo. Trabajos de Prehistoria 44, 267-270.

Jordá Cerdá, F., 1955. El Solutrense en España y sus problemas. Servicio de Investigaciones Arqueológicas, Diputación Provincial de Asturias, Oviedo.

Jordá Cerdá, F., Fortea, J., Corchón, M.S., 1992. Nuevos datos sobre la edad del Solutrense y Magdaleniense medio cantábrico. Las fechas de C14 de la Cueva de Las Caldas (Oviedo, España). Zephyrus 24-25, 13-16.

Jordá Pardo, J.F., 1992. Neógeno y Cuaternario del extremo oriental de la costa de Málaga. Ph. D. thesis, Departamento de Geología. Universidad de Salamanca, España.

Jordá Pardo, J.F., Aura Tortosa, J.E., 2009. El límite Pleistoceno-Holoceno en el yacimiento arqueológico de la Cueva de Nerja: nuevas aportaciones cronoestratigráficas y paleoclimáticas. Geogaceta 46, 95-98.

Le Brun-Ricalens, F., Brou, L., 2003. Burins carénés-nucléus à lamelles: identification d'une chaîne opératoire particulière à Temes (Yonne) et implications. Bulletin de la Société préhistorique française 100 (1), 67-83.

Mangado, X., Mercadal, O., Fullola, J.M., Grimao, J., 2009. In: Fullola, J.M., Valdeyron, N. (Eds.), Els Pirineus i les àrees circundants durant el Tardiglacial. Mutacions i Filiacions. XIV Col-loqui Internacional d'Arqueologia de Puigcerdà. Homenatge al Prof. Georges Laplace. Institu d'Estudis Ceretans, Puigcerdà, pp. 549-564.

Mangado, X., Tejero, J.M., Fullola, J.M., Petit, M.A., García-Argüelles, P., García, M., Soler, N., Vaquero, M., 2010. Nuevos territorios, nuevos grafismos: una visión del Paleolítico superior en Catalunya a inicios del siglo XXI. In: Mangado (Ed.), El Paleolítico superior peninsular. Novedades del siglo XXI. SERP, Universitat de Barcelona, Barcelona, pp. 63-83.

Meese, D., Alley, R., Gow, T., Grootes, P.M., Mayewski, P., Ram, M., Taylor, K., Waddington, E., Zielinski, G., 1994. Preliminary Depth-age Scale of the GISP2 Ice Core. CRREL Special Report 94-1. Cold Regions Research and Engineering Laboratory. Hanover, New Hampshire.

Montes, L., 2005. El magdaleniense en el Prepirineo aragonés: últimos hallazgos. Promontoria Monografica 02. In: Bicho, N. (Ed.), O Paleolítico, Actas do IV Congresso de Arqueologia peninsular. Universidade do Algarve, Faro, pp. 183-192.

Peñalver, X., Mujika, J.A., 2003. Suelo de ocupación magdaleniense en la cueva de Praile Aitz I (Deba, Guipúzcoa): evidencias de arte mobiliar. Veleia 20, 157-181.

Pericot, L., 1942. La Cova del Parpalló (Gandía, Valencia). C.S.I.C. Instituto Diego Velázquez, Madrid.

Rasilla Vives, M. de la, 1989. Secuencia y cronoestratigrafía del Solutrense cantábrico. Trabajos de Prehistoria 46, 35-46.

Rasilla Vives. de la, M., Llana Rodriguez, C., 1994. La cronología radiométrica del Solutrense en la Península Ibérica y su Correlación Crono-Climática. Monográfico sobre El Solutrense en la Península Ibérica, Férvedes 1, 57-67.
Rasilla Vives. de la, M., 1994. El Solutrense en la cornisa cantábrica. Monográfico El Solutrense en la Península Ibérica, Férvedes 1, 9-19.

Rasilla Vives de la, M., Santamaria, D., 2006. Tecnicidad y Territorio: las puntas de base cóncava del Solutrense cantábrico. Munibe 57 (2), 149-158.

Rasilla Vives de la, M., Straus, L.G., 2006. El poblamiento en la región cantábrica en torno al Último Máximo Glacial: Gravetiense y Solutrense. serie Anejos n 8. In: Fano, M.A. (Ed.), Las Sociedades del Paleolítico en la Región Cantábrica. KOBIE, Bilbao, pp. 209-242.

Ripoll López, S., 1988. La cueva de Ambrosio (Almería, Spain) y su posición cronoestratigráfica en el Mediterráneo occidental. Oxford. In: B.A.R. International Series, vol. 462.

Ripoll López, S. (Ed.), 1988. La Cueva de Ambrosio (Almería, Spain) y su posición cronoestratigráfica en el Mediterráneo Occidental. British Achaeological Reports, International Series, vol. 462. Oxford.

Ripoll López, S., Muñoz Ibañez, F.J., Latova Fernández-Luna, J., 2006. Nuevos datos para el arte rupestre paleolítico de La Cueva de Ambrosio (Vélez Blanco, Almería). In: Congreso de arte esquemático en la Península Ibérica. VélezRubio-Vélez-Blanco, (Almería 5-7 Mayo 2004), pp. 547-562. Almería.

Sacchi, D., 1986. Le Paléolithique supérieur du Languedoc occidental et du Roussillon. Gallia Préhistoire. Editions du CNRS, Suppl. 21, Paris.

Sauvet, G., Fortea, J., Fritz, C., Tosello, G., 2008. Crónica de los intercambios entre los grupos humanos paleolíticos. La contribución del arte para el periodo 20000-12000 años BP. Zephyrus 61, 33-59.

Séronie-Vivien, M.-R., 2005. In: Dujardin, V. (Ed.), L'industrie osseuse du Badegoulien de Pégourié (Caniac-du-Causse, Lot) et le décor pseudo-excisé. Actes du Table Ronde sur le Paléolithique récent, Angoulême 2003. Pôle éditorial archéologique de l'Ouest, Rennes, France, pp. 149-159.

Smith, Ph, 1966. Le Solutréen en France. Delmas, Bordeaux.

Soler, B., Badal, E., VIllaverde, V., Aura, J.E., 1990. Notas sobre un hogar Solútreogravetiense del Abric de la Ratlla del bubo (Crevillent, Alacant). Archivo de Prehistoria Levantina XX, 79-94.

Straus, L.G., 1975. ¿Solutrense o Magdaleniense inferior cantábrico? Significado de las diferencias. Boletin del Instituto de Estudios Asturianos 86, 781-790.

Straus, L.G., 1983. El Solutrense Vasco-Cantábrico: Una Nueva perspectiva. CIMA Santander, p. 10.

Straus, L.G., 1990. The original arms race: Iberian perspectives on the Solutrean phenomenon. In: Kozlowski, J.K. (Ed.), Feuilles de Pierre, vol. 42. ERAUL, pp. 425-477.

Straus, L.G., Clark, G.A. (Eds.), 1986. La Riera Cave. Stone Age Hunter-Gathere Adaptations in Northern Spain. Anthropological Research Papers, vol. 36. Arizona State University, Tempe.

Straus, L.G., González Morales, M.R., 2007. Further radiocarbon dates for the Upper Paleolithic of El Mirón Cave (Ramales de la Victoria, Cantabria, Spain). Radiocarbon 49 (3), 1205-1214.

Straus, L.G., González Morales, M.R., Stewart, E.B., 2008. Early Magdalenian variability: new evidence from El Mirón Cave, Cantabria, Spain. Journal of Field Archaeology 33 (2), 197-218. 367-369.

Tiffagom, M., 1998. Témoignages d'un traitement thermique des feuilles de laurier Dans le Solutréen superior de la Cova del Parpalló (Gandia, Espagne). Paléo 10 $147-162$.

Tiffagom, M., 2006. De la Pierre à l'Homme. Essai sur une Paéoanthropologie solutréenne. ERAUL, p. 113

Tiffagom, M., 2006b. El Solutrense de facies ibérica o la cuestión de los contactos mediterráneos (Europa, África) en el Último Máximo Glacial. In Sanchidrián, J.L., Márquez, A.M., Fullola, J.M. (Eds.), IV Simposio de Prehistoria Cueva de Nerja. La Cuenca Mediterránea durante el Paleolítico Superior 3800010000 años. Reunión de la VIII Comisión del Paleolítico Superior U.I.S.P. Fundación Cueva de Nerja. Nerja, pp. 60-77.

Utrilla, P., 1981. El Magdaleniense Inferior y Medio de la Costa Cantábrica. CIMA Santander, p. 4

Utrilla, P., 1986. La varilla pseudo-excisa de Aitzbitarte IV y sus paralelos franceses. Estudios en Homenaje al Profesor A. Beltran, pp. 205-225. Universidad de Zaragoza.

Utrilla, P., 1989. El magdaleniense inferior en la Costa Cantábrica. Actes du Colloque de Mayence (1987) “Le Magdalénien en Europe". ERAUL 38, 399-415.

Utrilla, P., 2006. Evolución histórica de las sociedades cantábricas durante el Tardiglacial: el Magdaleniense inicial, inferior y medio (16500-13000 BP). serie Anejos ${ }^{\circ}$ 8. In: Fano, M.A. (Ed.), Las Sociedades del Paleolítico en la Región Cantábrica. KOBIE, Bilbao, pp. 243-274.

Utrilla, P., González Sainz, C., 2003. La chronoestratigraphie du Magdalénien Cantabrique. In: Widemann, F., Taborin, Y. (Eds.), Chronologies géophysiques et archéologiques du Paléolithique Supérieur. Comptes rendís du Colloque International de Ravello (Mai 1994). Edpuglia, Bari, pp. 299-312.

Utrilla, P., Montes, L., 2007. La periode 19000-14000 BP Dans le Bassin de l'Ebre Bulletin de la Société préhistorique française 104, 797-807.

Utrilla, P., Montes, L., Mazo, C., Alday, A., Rodanés, J.M., Blasco, M.F., Domingo, R. Bea, J.M., 2010. In: Mangado, X. (Ed.), El Paleolítico superior peninsular. Novedades del siglo XXI. SERP, Universitat de Barcelona, Barcelona, pp. 23-61.

Vignard, E., 1965. Le Badegoulien. Bulletin de la Société préhistorique française 62 262-263.

Villaverde, V., 1994. Arte paleolítico de la Cova del Parpalló. Estudio de la colección de las plaquetas y cantos grabados y pintados. Museo de Prehistoria Valencia.

Villaverde, V., Fullola, J.M., 1990. Le Solutréen de la zone méditerranéenne espagnole. In: Kozlowski, J.K. (Ed.), Feuilles de pierre. Les industries à pointes foliase 
du Paléolithique supériur européen. Actes du Colloque de Cracovie, vol. 42. ERAUL, pp. 467-480.

Villaverde, V., Aura, J.E., Barton, C.M., 1998. The Upper Paleolithic in Mediterranean Spain: a review of current evidence. Journal of World Prehistory 12 (2) 121-198.

Villaverde, V., Martinez, R., Badal, E., Guillem, P., García, R., Menargues, J., 1999. E Paleolítico superior de la Cova de les Cendres (Teulada, Moraira). Datos proporcionados por el sondeo efectuado en los cuadros A/B 17. Archivo de Prehistoria Levantina XXIII, 6-65.

Weninger, B., Jöris, O., 2004. Glacial radiocarbon calibration. The CalPal Program. In: Higham, T., Bronk Ramsey, Ch., Owen, C. (Eds.), Radiocarbon and Archaeology.
Fourth International Symposium (Oxford, 2002). Oxford University School of Archaeology, Monograph, vol. 62, pp. 9-15.

Weninger, B., Jöris, O., Danzeglocke, U., 2012. Glacial Radiocarbon Age Conversion. Cologne Radiocarbon Calibration and Palaeoclimate Research Package $<$ CALPAL $>$ User Manual. Universität zu Köln, Institut für Ur- und Frühgeschichte, Köln. www.calpal.de.

Wang, Y.J., Cheng, H., Edwards, R.L., An, Z.S., Wu, J.Y., Shen, C.C., Dorale, J.A., 2001. A high-resolution Absolute-dated late Pleistocene Monsoon record from Hulu Cave, China. Science 294 (5550), 2345-2348.

Zilhão, J., 1997. O Paleolítico Superior da Estremadura Portuguesa, 2 vols.. Colibrí, Lisboa. 